\title{
MUZEUM PAPIERNICTWA W DUSZNIKACH-ZDROJU INICJATOREM SERYJNEJ NOMINACJI NA LISTĘ UNESCO NAJCENNIEJSZYCH EUROPEJSKICH MŁYNÓW PAPIERNICZYCH
}

\section{SZYMCZYK Maciej $^{1}$}

\section{${ }^{1}$ dr hab. Maciej Szymczyk, Muzeum Papiernictwa w Dusznikach Zroju https://orcid.org/0000-0002-8504-6483}

ABSTRAKT: Młyn papierniczy w Dusznikach-Zdroju powstał przed 1562 r. Dzięki opłacalności produkcji, przez wieki był rozbudowywany i zdobiony na wzór dworu szlacheckiego. Od 1968 r. jest siedzibą Muzeum Papiernictwa. W ostatnich latach wzrosła świadomość na temat wartości historycznej młyna. Staraniem muzeum w 2011 r. młyn uzyskał status pomnika historii, a w kolejnych latach podjęto zabiegi o wpisanie go na listę UNESCO. Zwiększeniu szans na wpis służy koncepcja seryjnej nominacji obejmującej najcenniejsze młyny papiernicze Europy. Polskie muzeum jest koordynatorem tego projektu. Dotąd podpisano porozumienia dotyczące starań o wspólną nominację z papierniami w Velkich Losinach z Czech i Homburga (dzielnica Triefenstein) w Niemczech, a rozmowy prowadzone są z papiernią w Ambert we Francji. Obecnie we współpracy z prof. Bogusławem Szmyginem muzeum opracowuje analizę porównawczą wszystkich zachowanych młynów papierniczych, która pozwoli wybrać 2-3 kolejnych partnerów.

SŁOWA KLUCZE: Papier, młyny papiernicze, papiernia w Dusznikach-Zdroju, papiernia w Velkich Losinach, papiernia w Homburgu, lista UNESCO

\section{Wstęp}

Od kilku dekad papier jest jednym z najpowszechniej na świecie wykorzystywanych produktów. Wg danych za 2017 r., we wszystkich krajach łącznie powstało $410 \mathrm{mln}$ ton, co w przeliczeniu na statystycznego mieszkańca globu daje $53,9 \mathrm{~kg}^{1}$. Masowa produkcja sprawia, że większość populacji ma dostęp do papieru, a mieszkańcy krajów rozwiniętych mogą wykorzystywać papier w sposób niemal nieograniczony. Niestety, traci on swe dawne kulturotwórcze znaczenie; dziś więcej 
papieru wykorzystujemy do pakowania innych produktów niż do pisania i drukowania ${ }^{2}$, co ma związek z rozwojem nowych technologii zapisywania, utrwalania i przekazywania informacji. $\mathrm{Z}$ całkowicie inną sytuacją mieli do czynienia nasi przodkowie. Papier wytwarzany w Europie od tysiąca lat, przez niemal dziewięć stuleci był produktem rzadkim, dostępnym ograniczonej liczbie ludności, a służył przede wszystkim do utrwalania wiedzy, przekazywania informacji czy też rozwoju i upowszechniania kultury.

\section{Zarys dziejów papiernictwa}

Podobnie jak wiele innych, istotnych dla naszej cywilizacji produktów, papier jest wynalazkiem chińskim, a sposób jego produkcji został opanowany w 105 r. n.e. ${ }^{3} \mathrm{~W}$ ciągu kilku stuleci sztuka wyrobu papieru została przeniesiona $z$ Chin do krajów sąsiednich. Pierwsze europejskie warsztaty papiernicze powstały po $1000 \mathrm{r}$. Zakładali je Arabowie na Półwyspie Iberyjskim, a zapewne także na Sycylii. W XIII stuleciu we Włoszech dokonano postępu w rozwoju wyrobu papieru. Jedną z głównych włoskich innowacji było zastosowanie stępy młotowej poruszanej energią wodną do przetwarzania surowca papierniczego (lnianych i konopnych szmat)4. Odtąd papiernie zaczęto nazywać młynami papierniczymi.

W kolejnych wiekach sztuka wyrobu papieru zakorzeniła się w większości europejskich krajów. Na ziemiach polskich pierwszy młyn papierniczy założono przed 1490 rokiem w należącym wówczas do Królestwa Czech Wrocławiu. W 1491 roku rozpoczęto budowę pierwszego młyna papierniczego w Królestwie Polskim - w Prądniku Czerwonym pod Krakowem. Pod koniec XVI wieku na obszarze Rzeczypospolitej czynnych było przynajmniej 56 papierni. Ich produkcja wg szacunkowych wyliczeń dawała pięć i pół arkusza na jednego mieszkańca w ciągu roku, co w skali Europy było wskaźnikiem wysokim, zważywszy że w niektórych krajach do tego czasu ledwie zapoczątkowano wyrób papieru ${ }^{5}$. Na ziemiach polskich, łącznie w różnych okresach, działało blisko 300 młynów papierniczych, a Polska zaliczana była do znaczących wytwórców papieru.

Od średniowiecza w Europie powstało kilka tysięcy młynów papierniczych. Schyłek ich epoki nastał dopiero w XIX stuleciu, wraz z upowszechnieniem fabryk, w których ręczną technikę czerpania arkuszy wyparła maszyna papiernicza wytwarzająca wstęgę papieru. Do dziś przetrwało nieco ponad 30 młynów pamiętających dawną epokę, w których nadal stosowana jest historyczna technika czerpania papieru.

2 W Polsce produkcja papieru do celów opakowaniowych w 2017 r. była 3,5 razy większa niż do pisania i drukowania. Obliczono na podst.: Godlewska K., Jastrzębski M., Zużycie i produkcja papieru i tektury w Polsce w 2017 r. na tle krajów europejskich, „Przegląd Papierniczy” 2018, nr 11, s. 686.

3 W literaturze przedmiotu pojawiają się także informacje o wytwarzaniu papieru w Chinach już od II-I wieku p.n.e. Papiernictwo. Dzieje, w: Encyklopedia ksiażki, t. 2 pod red. A. Żbikowskiej-Migoń i M. Skalskiej-Zlat, Wrocław 2017, s. 353.

4 Dąbrowski J., Siniarska-Czaplicka J., Rękodzieło papiernicze, Warszawa 1991, s. 69-70.

5 Ibidem, s. 319-320. 


\section{Burzliwe losy dusznickiego młyna papierniczego}

Jedna z zachowanych historycznych papierni znajduje się w Dusznikach-Zdroju nieopodal Kłodzka na Dolnym Śląsku. Jej początki datowane są na okres, gdy ziemia kłodzka, jako odrębne hrabstwo podlegała Królestwu Czech. Dziś nie sposób określić daty budowy dusznickiej papierni. Najwcześniejsze znane z jej dziejów wydarzenie, odnotowane w 1562 r., dotyczyło zakupu części udziałów w młynie przez Nikolausa Kretschmera. W rękach Kretschmerów papiernia znajdowała się do 1706 r. Drugi przedstawiciel tego rodu, Gregor, w 1607 r. uzyskał od cesarza Rudolfa II Habsburga herb, a przed 1612 r. również dziedziczny tytuł szlachecki, co wśród papierników było nobilitacją rzadko spotykaną. O szlacheckich aspiracjach papiernika świadczy fakt, że po powodzi z $1601 \mathrm{r}$. odbudował oraz rozbudował młyn w formie dworu. Kretschmerowie znacznie poszerzyli swój rynek zbytu. O ile w pierwszych dekadach działania zaopatrywali w papier lokalnych odbiorców, to pod koniec XVI wieku posiadali klientów we Wrocławiu. Po 1619 r. dusznicki papier pojawił się na Morawach, a w $1644 \mathrm{r}$. trafił nawet do Warszawy, gdzie stosowano go m.in. w kancelarii króla polskiego Władysława IV. W 1706 r. papiernię kupił Anton Heller. Drugi z Hellerów, Anton Benedikt, wprowadził nowatorski system przetwarzania szmat na masę papierniczą za pomocą młyna zwanego holendrem. Innowacja pozwoliła znacząco zwiększyć produkcję oraz poprawić jakość wytwarzanego w Dusznikach papieru. W 1742 r. Śląsk i ziemia kłodzka zostały przyłączone do Prus, a duszniccy papiernicy stali się poddanymi króla pruskiego. Wkrótce Heller przedłożył próbki swych produktów królewskim urzędnikom, a ich wysoka jakość zaowocowała przyznaniem mu w 1750 r. tytułu nadwornego papiernika króla Prus. W okresie rządów zięcia Hellera, Josepha Ossendorfa, wewnątrz młyna powstały malowidła ścienne wraz z najbardziej znaną biblijną sceną kuszenia Józefa przez żonę Putyfara. Kolejną właścicielką firmy była Antonia Josepha Ossendorf z domu Heller, której młyn zawdzięcza zachowaną do dziś ozdobną formę elewacji z nadokiennymi rozetami i półrozetami oraz pilastrami. W XIX wieku papiernia traciła na znaczeniu wskutek upowszechniania maszynowej techniki produkcji. Ostatni dusznicki papiernik Karl Wiehr, w 1939 r. sprzedał podupadający młyn miastu Duszniki, które planowało wykorzystać obiekt na muzeum.

Po II wojnie światowej ziemia kłodzka stała się częścią Polski. Nieczynny młyn znacjonalizowano, jednak początkowo brakowało koncepcji jego wykorzystania. Ważną decyzją dla papierni było zapewnienie jej w 1956 r. prawnej ochrony poprzez wpisanie do rejestru zabytków. W 1966 r. młyn przekazano państwowej branży papierniczej, a jego kierownikiem został Michał Kowalski, który opracował koncepcję funkcjonowania Muzeum Papiernictwa. Nowa placówka została otwarta dla zwiedzających 28 lipca 1968 r. W 1971 r. odtworzono produkcję papieru czerpanego, która prędko stała się znaczącą atrakcją turystyczną. W okresie adaptowania młyna na cele muzealne, na poddaszu odkryto tajemnicze malowidła. Stały się one sporym problemem dla kierownictwa muzeum, gdyż w tamtym czasie brakowało środków na ich zabezpieczenie. Dopiero w połowie lat 80. ubiegłego wieku znalazła się dotacja na konserwację polichromii, które udostępniono zwiedzającym w 1988 r. Ciągle brakowało wiedzy na temat okresu powstania dekoracji, jak też ich znaczenia. Przypuszczano, że jedno z malowideł nawiązuje do biblijnej historii kuszenia Józefa przez żonę Putyfara, jednak nie zdołano wówczas ustalić związku sceny z młynem.

W latach 1992-1998 muzeum podlegało pod Ministerstwo Przemysłu i Handlu. Wówczas 
przeprowadzono remont budynku i wymieniono ekspozycje. Pracownicy muzeum podjęli badania naukowe historii papiernictwa, a z czasem placówka stała się najważniejszym w Polsce ośrodkiem naukowym zajmującym się tą tematyką. Dobry okres przerwała w 1998 r. powódź, która spowodowała w młynie duże straty. Ponadto z początkiem 1999 r. muzeum zostało przejęte przez Samorząd Województwa Dolnośląskiego. Już w XXI wieku przeprowadzono remont więźby i dachu oraz udostępniono kolejne pomieszczenia papierni turystom. Ważnym osiągnięciem w zakresie ochrony przeciwpożarowej budynku było uruchomienie w 2016 r. systemu gaszenia wewnętrznego i zewnętrznego mgłą wodną ${ }^{6}$.

\section{Badania historyczne dusznickiej papierni}

Zainteresowanie historią dusznickiego młyna należy datować co najmniej od lat 80 . XVIII wieku, kiedy to informacje o dziejach papierni zostały opublikowane w obszernym opracowaniu Friedricha Alberta Zimmermanna Beyträge zur Beschreibung von Schlesien ${ }^{7}$. Niemieckojęzyczne opracowania na temat przeszłości młyna ukazywały się również w XIX i na początku XX wieku. Duże zainteresowanie polskich historyków papiernią odnotowano ponad pół wieku temu, a za najważniejsze polskie opracowania z tamtego okresu poświęcone papierni należy uznać analizę historyczno-architektoniczną Mariana Kutznera ${ }^{9}$ oraz publikację Wandy Tomaszewskiej ${ }^{10}$. Przez kolejne dekady posługiwano się ustaleniami niemieckich historyków z przełomu XIX i XX stulecia oraz polskich badaczy z lat 60. ubiegłego wieku.

Badania dziejów młyna zostały zintensyfikowane w 2007 r. dzięki utworzeniu pisma „Rocznik Muzeum Papiernictwa”. W pierwszych czterech tomach ukazał się słownik papierników śląskich autorstwa Rainera Sachsa i Doroty Błaszczyk ${ }^{11}$, w którym znalazły się informacje o dusznickich papiernikach. Inne ważne opracowanie wydrukowane w Roczniku, przygotowane przez dra Grzegorza Grajewskiego, dotyczyło losów młyna w pierwszych trzech dekadach XX w. ${ }^{12}$ W 2016 r. Muzeum Papiernictwa zapoczątkowało współpracę z Polskim Narodowym Komitetem

$6 \quad$ Szymczyk M., Sachs R., Eysymontt R., Bałchan J., Monografia mlyna papierniczego w Dusznikach-Zdroju, Duszniki-Zdrój 2018, s. 39-70, 333-336.

7 Pregiel P., Duszniki przez Zimmermanna opisane, „Rocznik Muzeum Papiernictwa” 2010, t. 4, s. 94-97.

8 Hohaus W., Die Papierfabrikation in der Grafschaft Glatz, "Vierteljahrsschrift für Geschichte und Heimatkunde der Grafschaft Glatz 1886/87, t. 6, s. 222-227, 325-329.

Szymczyk M., Źródła do dziejów dusznickiej papierni. Marian Kutzner, Studium historycznoarchitektoniczne papierni w Dusznikach, PKZ Wrocław 1960, "Rocznik Muzeum Papiernictwa" 2011, t. 5, s. 79-126.

10 Tomaszewska W., Z dziejów zabytkowej papierni w Dusznikach, „Przegląd Papierniczy” 1966, nr 5, s. 168173.

11 Błaszczyk D., Sachs R., Słownikpapierników śląskich do 1945 roku, cz. 1-4, „Rocznik Muzeum Papiernictwa”, 2007-2010, t. 1-4.

12 Grajewski G., O podejmowanych przed 1945 rokiem próbach ratowania mlyna papierniczego w DusznikachZdroju, „Rocznik Muzeum Papiernictwa”, 2015, t. 9. 
ICOMOS, której celem było opracowanie planu zarządzania pomnikiem historii1 ${ }^{13}$. Podczas wizyty w muzeum ówczesny prezes ICOMOS prof. Bogusław Szmygin zwrócił uwagę na artystyczne detale młyna - ozdobną elewację oraz polichromie, niezwykle rzadko spotykane w budynkach pełniących niegdyś funkcję produkcyjną. Oceniając ówczesny stan badań dotyczący młyna uznał, że dostępne analizy nie dają odpowiedzi na szereg pytań niezbędnych do określenia wartości zabytku. Opinia ta skłoniła muzeum do zainicjowania nowych badań architektonicznostylistycznych młyna, które zostały wykonane w ciągu dwóch kolejnych lat przez zespół pod kierunkiem prof. Rafała Eysymontta.

W 2017 r. muzeum zleciło znawcy sztuki śląskiej prof. Andrzejowi Koziełowi analizę historycznostylistyczną polichromii, wynikiem której było ustalenie okresu powstania malowideł, ich fundatora oraz prawdopodobnego twórcy. Ważnym efektem badań było odczytanie przekazu poszczególnych scen, w tym najciekawszej i dotąd najbardziej tajemniczej sceny kuszenia Józefa przez żonę Putyfara, jako odniesienia do losów fundatora malowideł - papiernika Josepfa Ossendorfa. Dalsze analizy dotyczyły właścicieli młyna, a zostały przeprowadzone przez specjalizującego się w badaniach archiwaliów Rainera Sachsa. Ich efektem było uporządkowanie listy papierników i ustalenie dokonań oraz pozycji społecznej każdego z nich. Wyniki badań posłużyły w 2018 r. do opracowania dwóch wydawnictw: popularno-naukowej książki Młyn papierniczy w Dusznikach-Zdroju ${ }^{14}$ oraz naukowej Monografii mlyna papierniczego ${ }^{15}$, dzięki którym dziś dusznicka papiernia jest obiektem o wzorcowo udokumentowanej historii.

\section{Wzrost świadomości o wartości młyna}

W wyniku prowadzonych badań naukowych oraz rosnącego zainteresowania zabytkowym obiektem ze strony turystów, w ostatniej dekadzie nastąpił znaczący wzrost świadomości na temat wartości historycznej papierni. Atrakcyjność młyna papierniczego zaowocowała w 2009 r. zaliczeniem go przez Polską Organizację Turystyczną do największych atrakcji turystycznych kraju. Muzeum znalazło się w opracowanej 3 lata później publikacji „Najlepsze produkty turystyczne Polski 2003-2012"16, zawierającej certyfikowane produkty turystyczne dziesięciolecia. $\mathrm{W}$ ostatnich latach roczna liczba zwiedzających papiernię kształtuje się na poziomie ok. 65 tys. osób, co stawia placówkę w pierwszej trójce muzeów o najwyższej zwiedzalności na Dolnym Śląsku.

W 2008 r. muzeum podjęło prace nad przygotowaniem wniosku o wpisanie młyna papierniczego na listę pomników historii. Zwieńczeniem trwających 3 lata starań było wydanie rozporządzenia

13 Plan zarządzania został opracowany w latach 2016-2017, a następnie wydany w polskiej i angielskiej wersji językowej. Szmygin B., Fortuna-Marek A., Siwek A., Ocena wartości i plan zarządzania Młyna Papierniczego w Dusznikach-Zdroju, Lublin 2017; Szmygin B., Fortuna-Marek A., Siwek A., Paper mill in Duszniki-Zdrój valueassessment and management plan, Lublin - Duszniki-Zdrój 2018.

$14 \quad$ Eysymonnt R., Sachs R., Szymczyk M., Młyn papierniczy w Dusznikach-Zdroju, Duszniki-Zdrój 2018 (książka wydana w j. polskim, czeskim, niemieckim i angielskim).

15 Szymczyk M., Sachs R., Eysymontt R., Bałchan J., Monografia mlyna papierniczego ...

16 Najlepsze produkty turystyczne Polski 2003-2012, http://pdf.polska.travel/certyfikaty-pot/pl/ (dostęp 23.05.2019). 


\section{Maciej Szymczyk}

przez Prezydenta Rzeczypospolitej Polskiej w dniu 20 września 2011 r. uznającego papiernię pomnikiem historii ${ }^{17}$.

W 2013 r. minister kultury i dziedzictwa narodowego wpisał Muzeum Papiernictwa do Państwowego Rejestru Muzeów, skupiającego placówki muzealne o największym znaczeniu dla kultury narodowej. Wg opinii ministerstwa „wyjątkowy charakter profilu muzeum, jego niezwykła siedziba, wysoki poziom zarządzania (...) stawia tę instytucję muzealną w szeregu najważniejszych dla polskiego dziedzictwa kulturowego"18.

\section{Koncepcja wpisu na listę UNESCO młynów papierniczych}

Zaliczenie dusznickiej papierni do grona obiektów najcenniejszych dla kultury polskiej zrodziło pytania o znaczenie młyna w kontekście międzynarodowym. Wstępna analiza wartości obiektu przeprowadzona wewnątrz muzeum wykazała, że wyróżnia się on na tle innych młynów papierniczych estetyką i stanem zachowania. Zachęciło to kierownictwo muzeum do podjęcia starań o wpisanie młyna na listę światowego dziedzictwa UNESCO.

Spośród obiektów związanych z papiernictwem, na tę prestiżową listę dotąd wpisano pochodzącą z końca XIX wieku fabrykę tektury i ścieru drzewnego wraz z osiedlem robotniczym w Verli w Finlandii. Jednak fiński zakład pochodzący z okresu przemysłowego, stosował od początku swej egzystencji maszynową technikę produkcji ${ }^{19}$, zatem znacząco różnił się od młynów opierających swą działalność na ręcznej produkcji papieru. Spośród zachowanych w Europie młynów papierniczych, próbę wpisu na listę UNESCO podjęto jedynie w przypadku papierni z Velkich Losin w Czechach. W latach 2002-2004 r. opracowano wniosek o nominację, jednak wg oceny ICOMOS-u przekazanej światowemu Komitetowi UNESCO, papiernia w Velkich Losinach nie powinna być rozpatrywana wg propozycji Czech, lecz należy wziąć pod uwagę możliwość przygotowania nominacji o szerszym zakresie, obejmującej obok papierni w Velkich Losinach także serię innych obiektów związanych z historią papieru i druku ${ }^{20}$.

Doświadczenia czeskie wskazywały, że przygotowanie nominacji jednego młyna papierniczego nie spotka się z aprobatą ICOMOS-u. Dlatego kolejnym krokiem Muzeum Papiernictwa było podjęcie współpracy z zarządem papierni w Velkich Losinach w celu przygotowania wspólnego wniosku. W związku z tym, że czeska papiernia znajdowała się już na liście informacyjnej UNESCO, zamierzeniem muzeum stało się zgłoszenie dusznickiego młyna na polską listę informacyjną.

Do opracowywania zgłoszenia kandydatury dusznickiego młyna na polską listę informacyjną

$17 \quad$ Rozporzadzenie Prezydenta Rzeczypospolitej Polskiej z dnia 20 września 2011 r. w sprawie uznania za Pomnik Historii „Duszniki-Zdrój - mlyn papierniczy”, „Dziennik Ustaw” 2011, nr 217, poz. 1282.

18 Nowicka M., Szymczyk M., Muzeum Papiernictwa w Państwowym Rejestrze Muzeów, „Rocznik Muzeum Papiernictwa" 2013, t. 7, s. 108.

19 Verla Groundwood and Board Mill, http://whc.unesco.org/en/list/751 (dostęp 2.06.2019).

$20 \quad$ Handmade paper mill (Czech Republic). No 1235, w: UNESCO World Heritage Convention, Evaluations of cultural properties, ICOMOS 2007, s. 136, http://whc.unesco.org/archive/2007/whc07-31com-inf8ble.pdf (dostęp 23.05.2019). 
przystąpiono w 2013 r. we współpracy z Grzegorzem Grajewskim - szefem dolnośląskiego oddziału terenowego Narodowego Instytutu Dziedzictwa, z założeniem że wniosek winien przewidywać transgraniczny wpis seryjny młynów z Polski i Czech. 24 lutego 2014 r. Muzeum Papiernictwa przesłało wniosek wraz $\mathrm{z}$ dokumentacją młyna do Narodowego Instytutu Dziedzictwa $^{21}$. Oceniający zgłoszenie Komitet ds. Światowego Dziedzictwa Kulturowego w Polsce stwierdził, że młyn papierniczy ma szanse wpisu na listę UNESCO jako wpis seryjny. Dlatego wskazał konieczność rozpoznania stanowiska Czech w sprawie współpracy przy przygotowywaniu transgranicznego wpisu seryjnego obejmującego młyny z Dusznik i Velkich $\operatorname{Losin}^{22}$.

Realizując wniosek Komitetu, Narodowy Instytut Dziedzictwa zwrócił się do Narodnego Pamiatkowego Ustavu (swego odpowiednika w Czechach) w sprawie ewentualnych wspólnych starań o wpisanie na listę UNESCO polskiego i czeskiego młyna. Strona czeska nie widząc przeciwskazań do takiej nominacji stwierdzała jednak, że aktualnie realizuje inne zadania. Jednocześnie przedstawiła sugestię, aby rozważyć przygotowanie wpisu zgodnie z rekomendacją ICOMOS-u, szerszego niż wspomniane dwa młyny ${ }^{23}$. Muzeum również zintensyfikowało współpracę z czeskim partnerem i 15 kwietnia 2015 r. w dusznickim młynie papierniczym został podpisany list intencyjny dotyczący współpracy pomiędzy polską i czeską instytucją w zakresie dążeń do wpisania obydwu papierni na listę UNESCO ${ }^{24}$.

Projektem papierni z Polski i Czech zainteresował się Wydział Współpracy z Zagranicą Urzędu Marszałkowskiego Województwa Dolnośląskiego, który w styczniu 2016 r. zorganizował we Wrocławiu naradę z udziałem przedstawicieli kilku wydziałów, dyrektorów obydwu młynów papierniczych: Macieja Szymczyka i Petra Foučka oraz szefa Europejskiego Ugrupowania Współpracy Terytorialnej NOVUM Bartosza Bartniczaka. Efektem spotkania było zaangażowanie się w projekt EUWT NOVUM. To właśnie EUWT pozyskało dofinansowanie z Ministerstwa Spraw Zagranicznych na konferencję poświęconą przygotowaniu wspólnej nominacji polskiej i czeskiej papierni. Zorganizowano ją w dniach 6-7 października $2016 \mathrm{r}$. w Dusznikach-Zdroju pod tytułem „Na szlaku wspólnego dziedzictwa”. Udział w przedsięwzięciu wzięli przedstawiciele władz Województwa Dolnośląskiego, Narodowego Instytutu Dziedzictwa i czeskiego Narodnego Pamiatkowego Ustavu, naukowcy oraz dziennikarze. Podczas konferencji została m.in. zaprezentowana przez reprezentującą ICOMOS Annę Fortunę-Marek analiza wartości papierni jako punkt wyjścia do opracowania planu zarządzania. Uczestnicy konferencji mieli okazję obejrzeć i porównać obydwa młyny papiernicze.

Istotnym wydarzeniem wieńczącym starania muzeum o zgłoszenie młyna papierniczego na listę informacyjną była uchwała Komitetu ds. Światowego Dziedzictwa Kulturowego w Polsce, podjęta w dniu 30 listopada 2016 r., zawierająca pozytywną rekomendację dla wniosku

\footnotetext{
${ }^{21}$ Archiwum Zakładowe Muzeum Papiernictwa (dalej AZMP), Pismo Muzeum do NID z 24.02.2014 r., w sprawie wniosku o wpisanie na listę informacyjną młyna papierniczego, sygn. DN.061, 2014, T. II, s. 64.

22 AZMP, Uchwała nr 16 Komitetu do spraw Światowego Dziedzictwa Kulturowego w Polsce z 23.10.2014 r., sygn. DN.062, 2015, s. 46.

${ }_{23}$ AZMP, Pismo dyr. NID do dyr. Muzeum z dnia 10.08.2015 r., sygn. DN.062, 2015, s. 49-51.

24 Kacperowska D., Kronika 2015 roku, „Rocznik Muzeum Papiernictwa” 2016, t. 10, s. 140-145.
} 
seryjnego z wyjściowymi dwoma obiektami: polskim młynem papierniczym w DusznikachZdroju i czeskim młynem w Velkich Losinach. W uchwale znalazła się również rekomendacja wykonania szerokiej analizy porównawczej w celu ewentualnego rozszerzenia wniosku o inne obiekty ${ }^{25}$.

Muzeum realizując zalecenia Komitetu podsumowało wiedzę na temat zachowanych do dziś młynów papierniczych w Europie, w celu określenia obiektów, o które można będzie poszerzyć nominację. Po analizie historii i cech poszczególnych młynów, zwrócono uwagę na papiernię w Homburgu (obecnie dzielnica miasta Triefenstein w powiecie Main Spessart), leżącego na terenie Bawarii. Papiernia posiadając konstrukcję typową dla młynów papierniczych jest doskonałym świadectwem architektury tego typu budowli. Jednak wyróżnia się tym, że pierwotnie wybudowana była w innym miejscu, a na początku XIX wieku została rozebrana i przeniesiona do Homburga ${ }^{26}$.

Na przełomie listopada i grudnia 2017 r. w Dusznikach-Zdroju odbyła się druga konferencja w sprawie młynów papierniczych, z udziałem trzeciego partnera, Johannesa Follmera przedstawiciela papierni w Homburgu. W jej trakcie został podpisany list intencyjny dotyczący współpracy pomiędzy papierniami z Dusznik, Velkich Losin i Homburga. Na zakończenie konferencji odbyła się narada przedstawicieli młynów papierniczych z udziałem prof. Bogusława Szmygina - prezesa Polskiego Narodowego Komitetu ICOMOS, której wynikiem było ustalenie dalszych działań grupy. Na koordynatora zadania zostało wybrane Muzeum Papiernictwa. W celu przygotowania możliwie kompletnej nominacji, postanowiono ustalić kolejnych potencjalnych partnerów, wstępnie uznając, że powinna ona obejmować 5-6 młynów papierniczych ${ }^{27}$.

W maju 2018 r. w Velkich Losinach została zorganizowana trzecia międzynarodowa konferencja. W jej trakcie przedstawiciele papierni z Polski, Czech i Niemiec potwierdzili zamiar dalszej współpracy. Ponadto stwierdzono konieczność poszerzenia grupy o inne młyny oraz za zasadne uznano dalsze badania dziejów poszczególnych papierni ${ }^{28}$. Krótko później nawiązano współpracę z młynem papierniczym Richard de Bas z miejscowości Ambert we Francji, zaliczanym do najstarszych papierni w Europie.

W 2019 r. dzięki pozyskaniu środków z budżetu Samorządu Województwa Dolnośląskiego, wspólnie ze środowiskiem naukowców pod kierunkiem prof. Bogusława Szmygina, z udziałem prof. Rafała Eysymontta, Muzeum Papiernictwa przystąpiło do opracowania pierwszego etapu analizy porównawczej europejskich młynów papierniczych, która będzie częścią wspólnej nominacji. Opracowanie posłuży do wyboru innych potencjalnych partnerów do seryjnego wpisu historycznych papierni na listę UNESCO.

25 Dokumentacja bieżąca Muzeum Papiernictwa. Uchwała nr 33 Komitetu ds. Światowego Dziedzictwa Kulturowego w Polsce z 30.11.2016 r. w sprawie propozycji umieszczenia na polskiej Liście informacyjnej młyna papierniczego w Dusznikach-Zdroju, teka DN.062.16.2017.

26 Späth A., Museum Papiermühle Homburg, München 1999, s. 17-19.

27 Dokumentacja bieżąca Muzeum Papiernictwa. Protokół ze spotkania (1 XII 2017, Hotel Impresja w Dusznikach-Zdroju).

28 Dokumentacja bieżąca Muzeum Papiernictwa. Protokół ze spotkania (16 V 2018, Hotel Diana Velke Losiny). 


\section{Podsumowanie}

Projekt, którego pierwotnym celem było wpisanie na listę UNESCO dusznickiej papierni, w kolejnych latach przekształcił się w międzynarodową inicjatywę współpracy pomiędzy muzeami zarządzającymi młynami papierniczymi w Polsce, Czechach, Niemczech i Francji. W efekcie prowadzonych obecnie przez zespół pod kierunkiem prof. Bogusława Szmygina prac porównawczych wszystkich dawnych europejskich papierni, koncepcja może zostać poszerzona o dalsze 2-3 młyny.

Projekt wpisu na listę UNESCO najcenniejszych europejskich młynów papierniczych znacząco zmienił pozycję dusznickiego Muzeum Papiernictwa, które koordynując wspólne działania wywiera decydujący wpływ na całą koncepcję nominacji. Rozmiar projektu wymaga ogromnego zaangażowania organizacyjnego, co powoduje konieczność udzielenia wsparcia muzeum przez Ministerstwo Kultury i Dziedzictwa Narodowego. Mogłoby to zostać zrealizowane poprzez współprowadzenie dusznickiego muzeum przez ministerstwo oraz Samorząd Województwa Dolnośląskiego. Formuła współprowadzenia pozwoliłaby znacznie zwiększyć wydolność organizacyjną placówki i przyczyniłaby się do sprawniejszej realizacji zadań związanych z przygotowywaniem seryjnej międzynarodowej nominacji pod kierownictwem Polski.

Najważniejszym z punktu widzenia młyna papierniczego osiągniętym dotąd efektem starań o nominację, jest wzrost świadomości na temat historycznej wartości obiektu. Sprzyjają temu przeprowadzone w ostatnich latach badania naukowe, dzięki którym obecnie młyn jest jednym z najlepiej poznanych reliktów dawnego papiernictwa w Europie. Wiedza na temat wyjątkowej wartości obiektu nakazuje otoczyć go szczególną opieką. W 2016 r. cały kompleks budynków został zabezpieczony systemem gaszenia mgłą. Obecnie projektowana jest przez administrację państwową budowa kanału ulgi, który będzie stanowił zabezpieczenie przeciwpowodziowe młyna.

Konieczność zachowania historycznej papierni w dobrym stanie dla przyszłych pokoleń wymaga odpowiednich nakładów na prace remontowe. Wypada mieć nadzieję, że również w tej dziedzinie niebawem nadejdą sukcesy pozwalające realizować niezbędne remonty i umożliwiające racjonalne wykorzystanie obiektu na cele muzealne. 


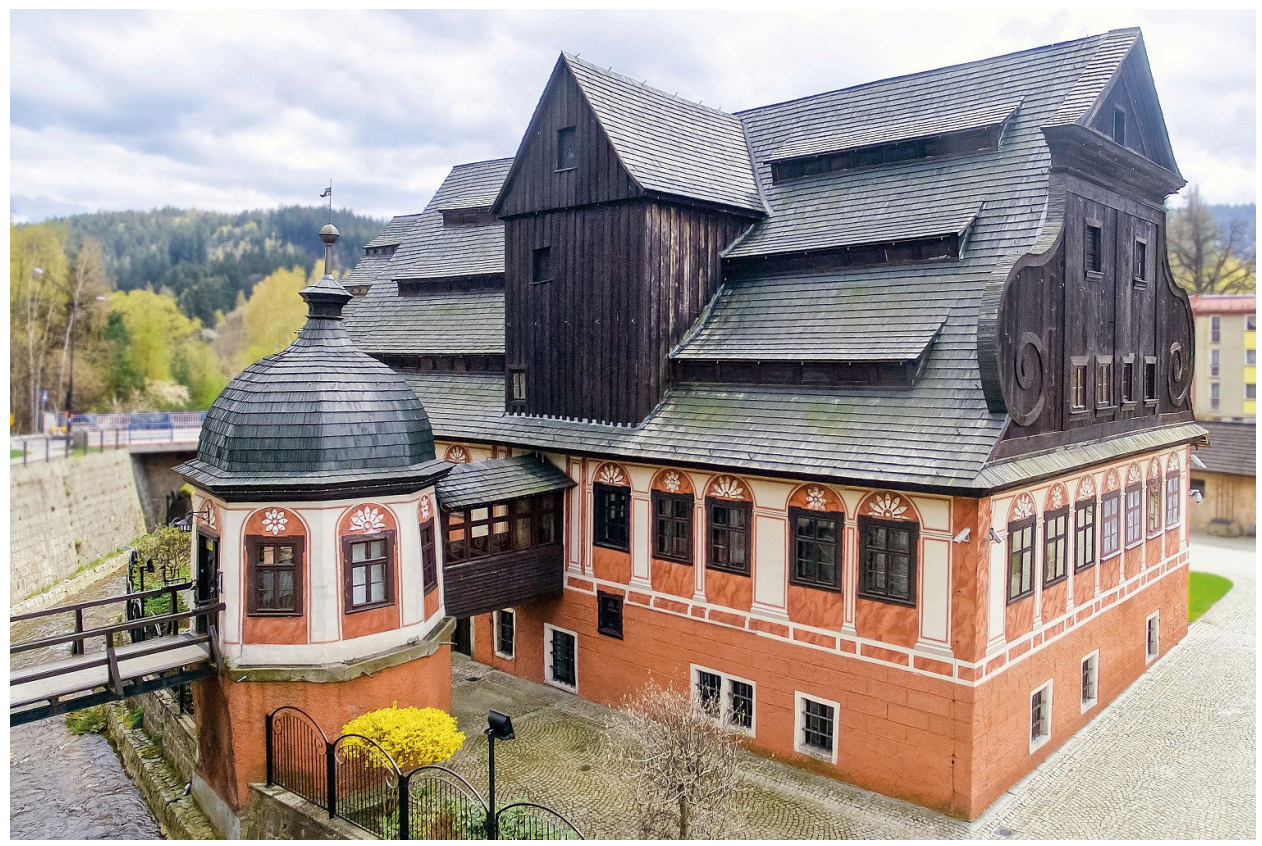

Fot. 1 Młyn papierniczy w Dusznikach-Zdroju, fot. Mariusz Młynarczyk (MKiDN)

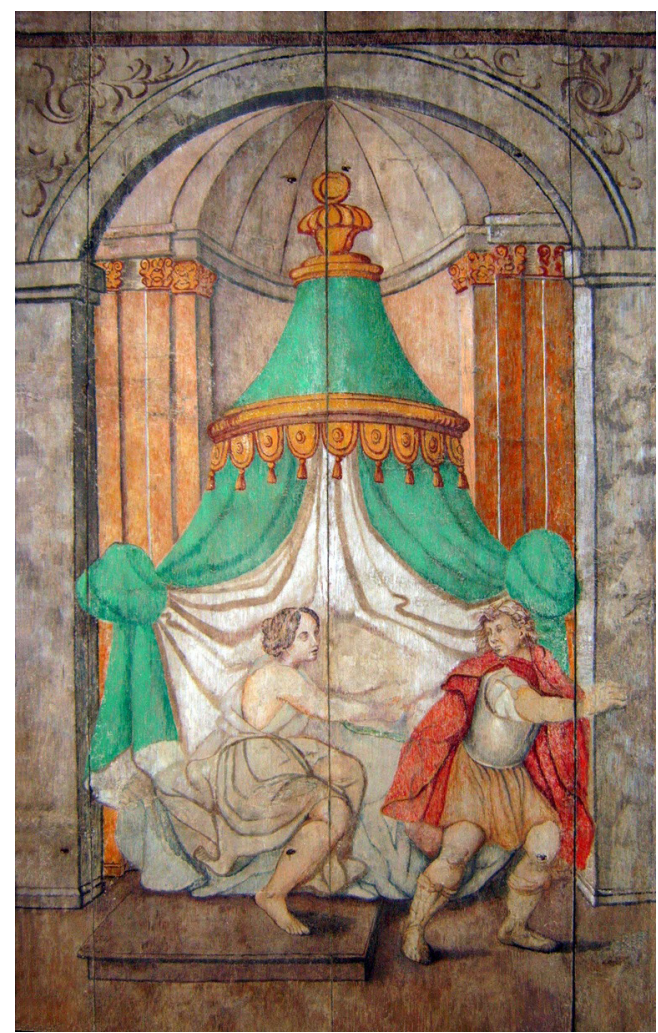

Fot. 2 Malowidło z biblijną sceną kuszenia Józefa przez żonę Putyfara, fot. Krzysztof Jankowski 


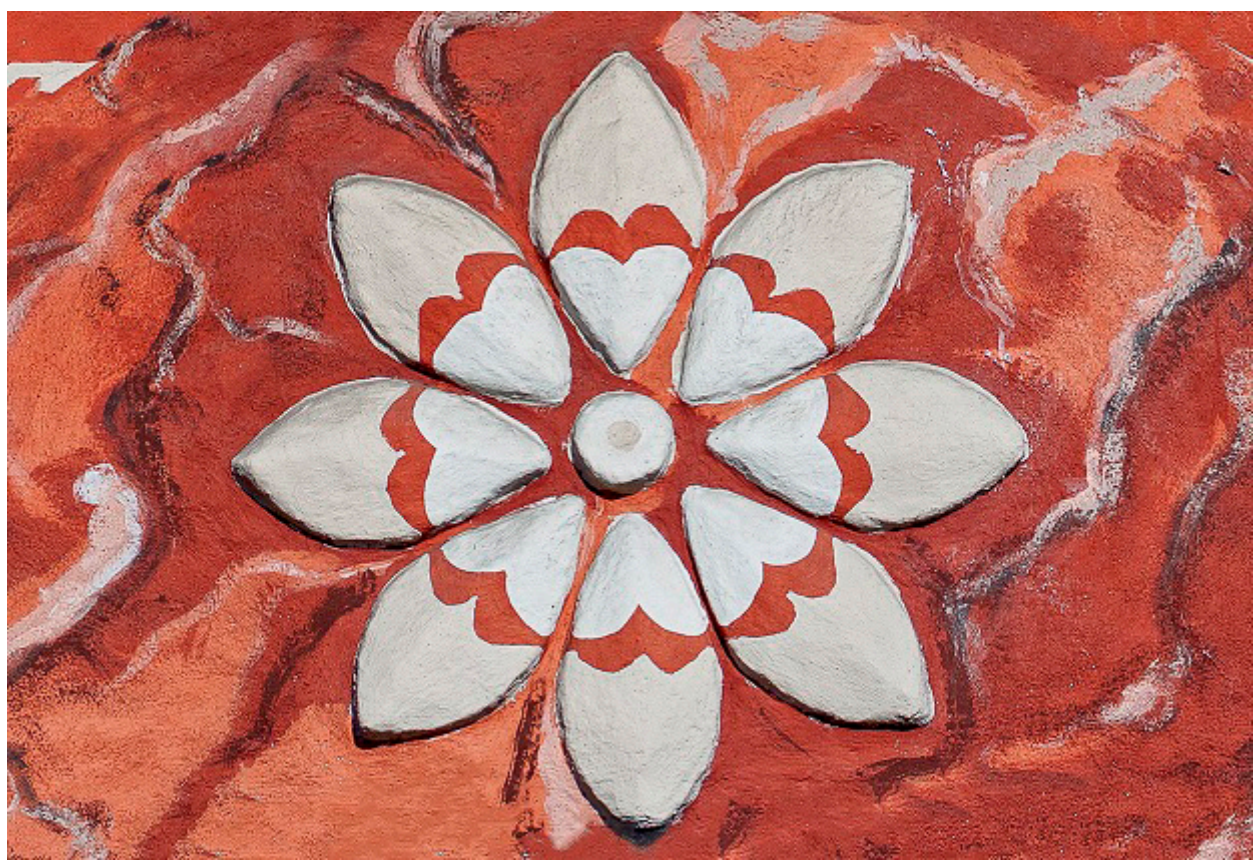

Fot. 3 Rozeta nadokienna, fot. Krzysztof Jankowski

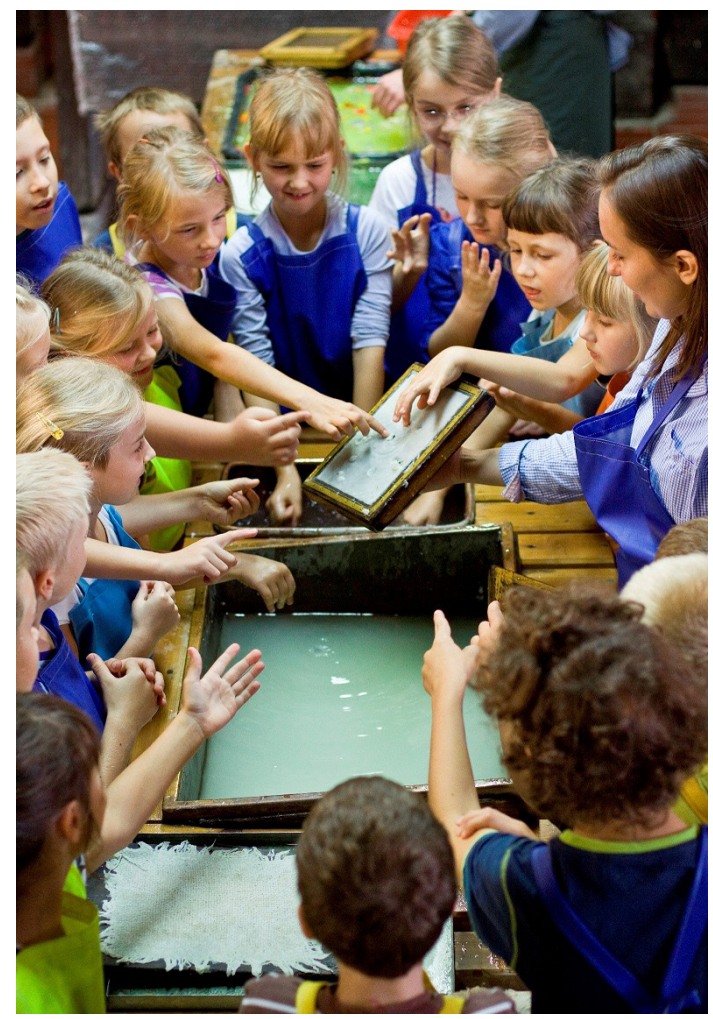

Fot. 4 Czerpanie papieru wg dawnej techniki na zajęciach edukacyjnych, fot. Tomasz Szewczyk 


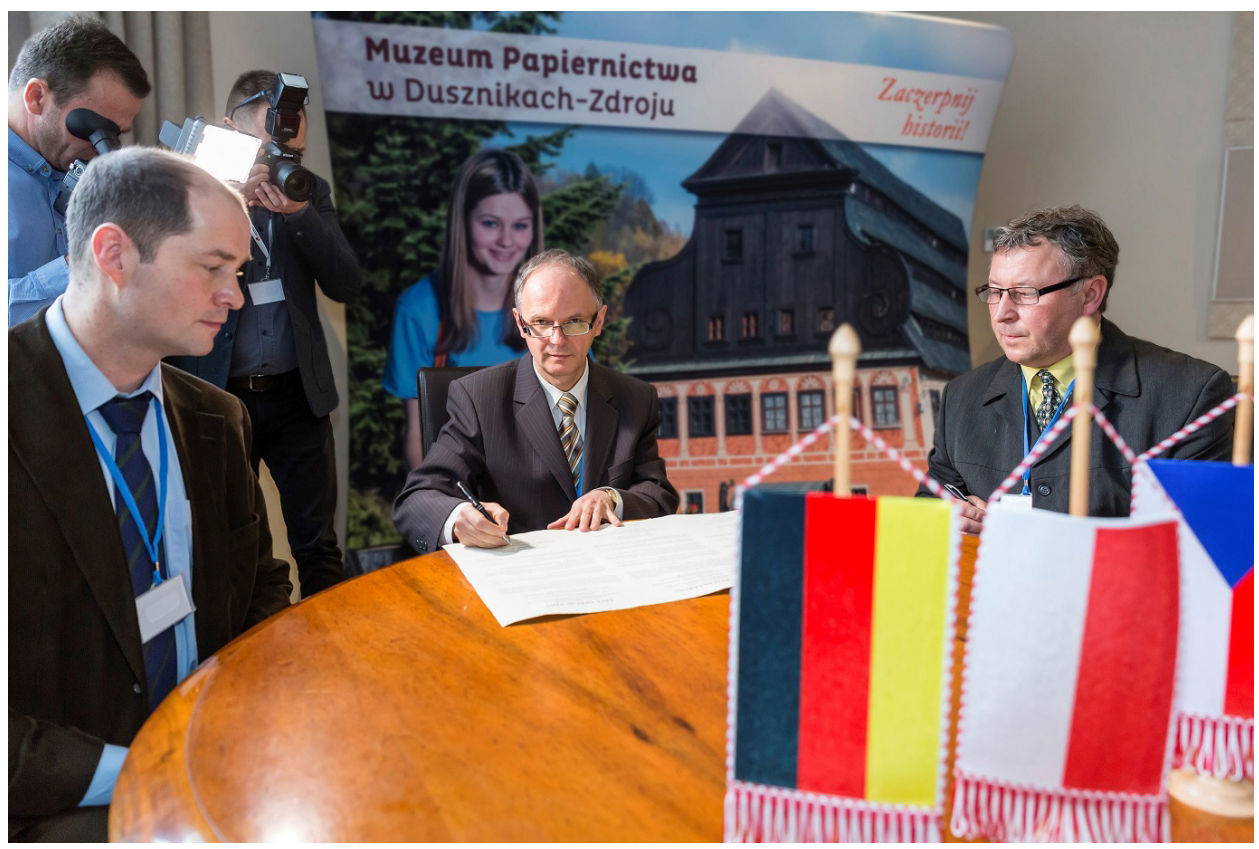

Fot. 5 Podpisanie porozumienia o współpracy pomiędzy przedstawicielami młynów papierniczych z Polski, Czech i Niemiec, fot. Krzysztof Jankowski

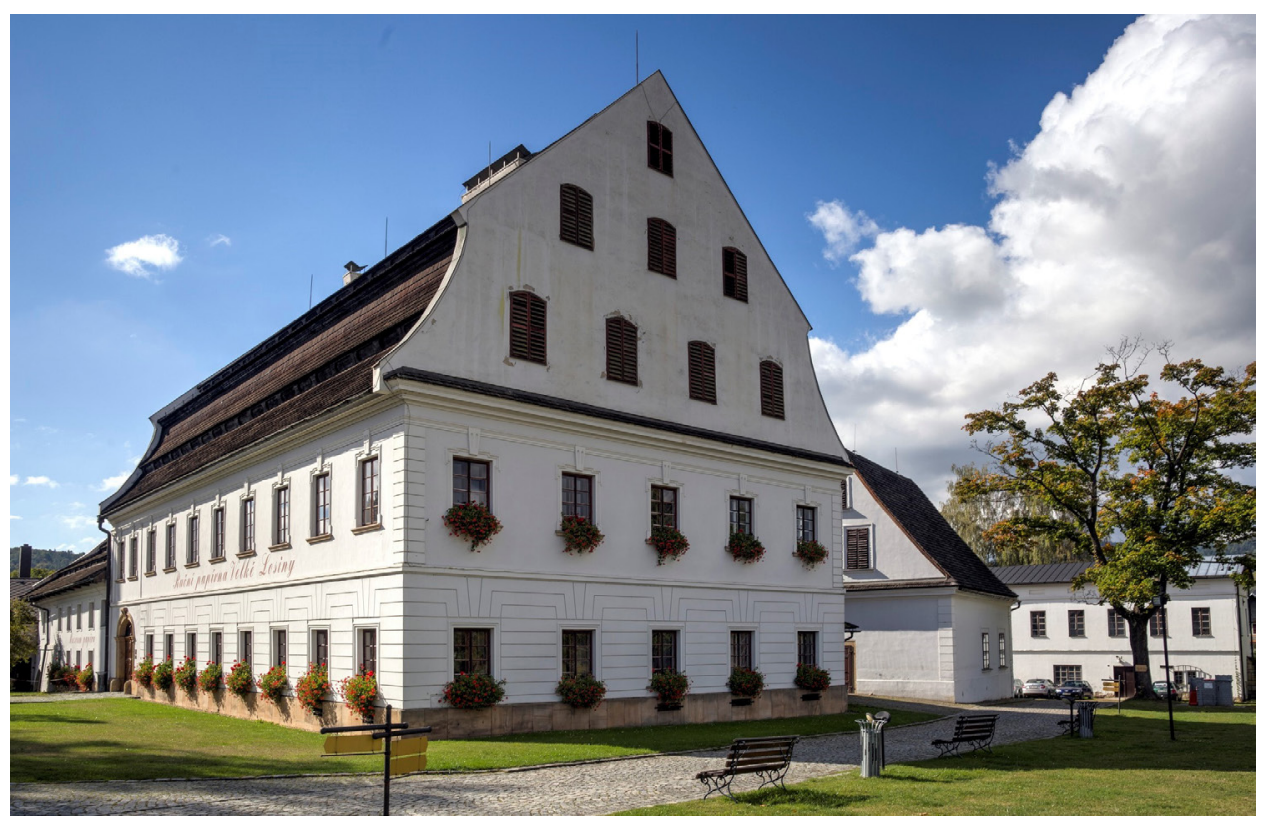

Fot. 6 Papiernia w Velkich Losinach, fot. Krzysztof Jankowski 


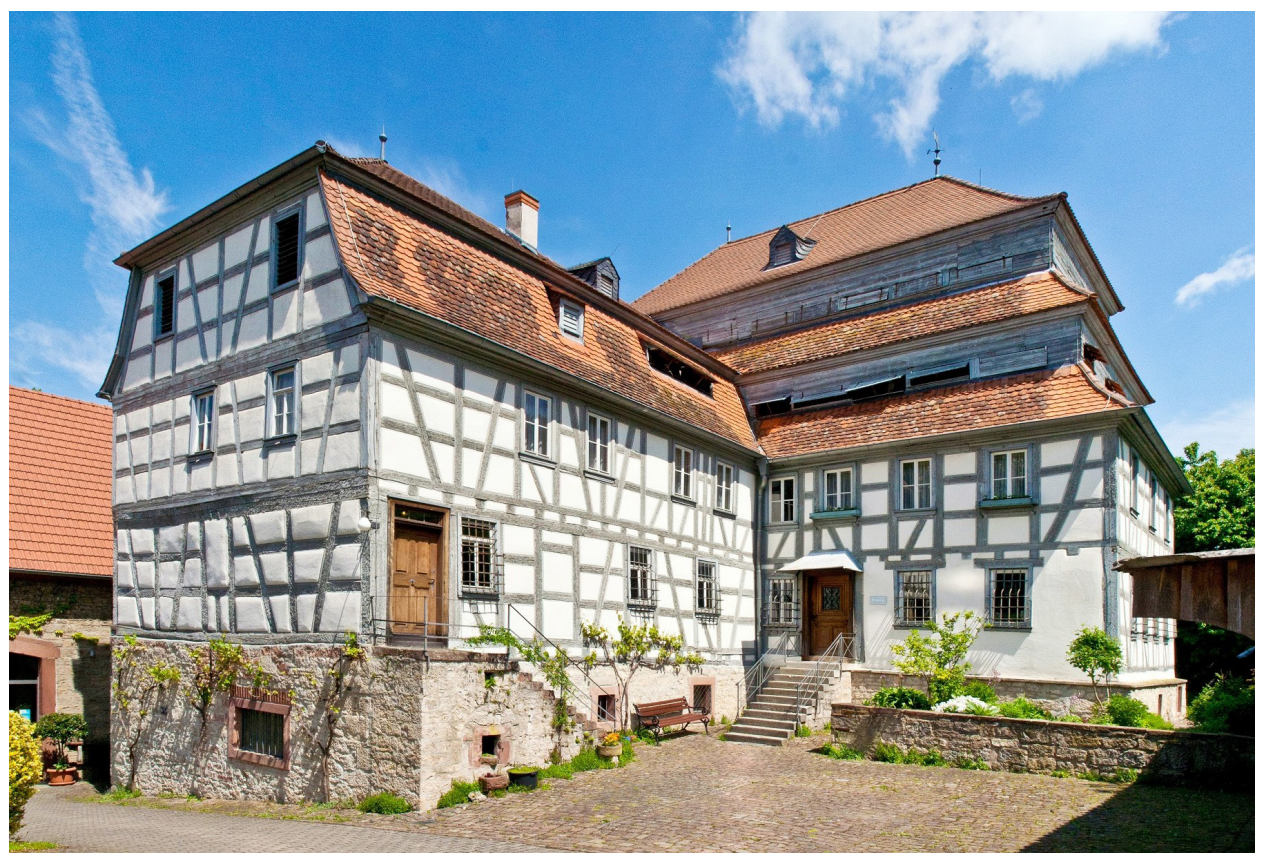

Fot. 7 Papiernia w Homburgu, fot. Oliver Wieser 


\section{Bibliografia}

\section{Publikacje}

Dąbrowski J., Siniarska-Czaplicka J. (1991). Rękodzieło papiernicze, Warszawa: Sigma NOT.

Eysymonnt R., Sachs R., Szymczyk M. (2018). Młyn papierniczy w Dusznikach-Zdroju, DusznikiZdrój: Muzeum Papiernictwa w Dusznikach Zdroju.

Godlewska K., Jastrzębski M. (2018). Zużycie i produkcja papieru i tektury w Polsce w 2017 r. na tle krajów europejskich, Przegląd Papierniczy, nr 11, 681-689.

Handmade paper mill (Czech Republic). (2007). UNESCO World Heritage Convention, Evaluations of cultural properties (129-136). Christchurch (New Zealand) ICOMOS, http://whc.unesco.org/ archive/2007/whc07-31com-inf8ble.pdf.

Hohaus W. (1886/870). Die Papierfabrikation in der Grafschaft Glatz, Vierteljahrsschrift für Geschichte und Heimatkunde der Grafschaft Glatz, t. 6, 222-227, 325-329.

Kacperowska D. (2016). Kronika 2015 roku, Rocznik Muzeum Papiernictwa. t. 10, 133-170.

Maleczyńska K. (2017). Papiernictwo. Dzieje, Żbikowska-Migoń A., Skalska-Zlat M., Encyklopedia ksiązki, t. 2, Wrocław: Wydawnictwo Uniwersytetu Wrocławskiego (353-357).

Najlepsze produkty turystyczne Polski 2003-2012. (2012) http://pdf.polska.travel/certyfikaty-pot/ $\mathrm{pl} /$.

Nowicka M., Szymczyk M. (2013). Muzeum Papiernictwa w Państwowym Rejestrze Muzeów, Rocznik Muzeum Papiernictwa, t. 7, 105-108.

Pregiel P. (2010). Duszniki przez Zimmermanna opisane, Rocznik Muzeum Papiernictwa, t. 4, 94-97.

Rocznik statystyczny Rzeczypospolitej (2018). Warszawa: Główny Urząd Statystyczny

Rozporządzenie Prezydenta Rzeczypospolitej Polskiej z dnia 20 września 2011 r. w sprawie uznania za pomnik historii „Duszniki-Zdrój - młyn papierniczy”. (2011). Dziennik Ustaw, nr 217, poz. 1282.

Späth A. (1999) Museum Papiermühle Homburg, München: Weltkunst Verlag.

Szmygin B., Fortuna-Marek A., Siwek A. (2017). Ocena wartości i plan zarzadzania Młyna Papierniczego w Dusznikach-Zdroju, Lublin: Wydawnictwo Politechniki Lubelskiej.

Szmygin B., Fortuna-Marek A., Siwek A. (2018). Paper mill in Duszniki-Zdrój - value assessment and management plan, Lublin - Duszniki-Zdrój: Wydawnictwo Politechniki Lubelskiej, Muzeum Papiernictwa w Dusznikach Zdroju.

Szymczyk M., Sachs R., Eysymontt R., Bałchan J. (2018). Monografia mlyna papierniczego w Dusznikach-Zdroju. Duszniki-Zdrój: Muzeum Papiernictwa w Dusznikach-Zdroju.

Szymczyk M. (2011). Źródła do dziejów dusznickiej papierni. M. Kutzner, Studium historycznoarchitektoniczne papierni w Dusznikach, PKZ Wrocław 1960, Rocznik Muzeum Papiernictwa, t. 5, 79-126.

Tomaszewska W. (1966). Z dziejów zabytkowej papierni w Dusznikach, Przegląd Papierniczy, nr $5,168-173$. 
Verla Groundwood and Board Mill, http://whc.unesco.org/en/list/751.

\section{Dokumenty archiwalne}

Archiwum Zakładowe Muzeum Papiernictwa, Pismo Muzeum Papiernictwa do Narodowego Instytutu Dziedzictwa z 24.02.2014 r., w sprawie wniosku o wpisanie na listę informacyjną młyna papierniczego, sygn. DN.061, 2014, T. II, s. 64.

Archiwum Zakładowe Muzeum Papiernictwa, Pismo prof. M. Rozbickiej do dyr. Muzeum Papiernictwa z dnia 10.08.2015 r., sygn. DN.062, 2015, s. 49-51.

Archiwum Zakładowe Muzeum Papiernictwa, Uchwała nr 16 Komitetu do spraw Światowego Dziedzictwa Kulturowego w Polsce z 23.10.2014 r., sygn. DN.062, 2015, s. 46.

Dokumentacja bieżąca Muzeum Papiernictwa. Protokół ze spotkania (1 XII 2017, Hotel Impresja w Dusznikach-Zdroju).

Dokumentacja bieżąca Muzeum Papiernictwa. Protokół ze spotkania (16 V 2018, Hotel Diana Velke Losiny).

Dokumentacja bieżąca Muzeum Papiernictwa. Uchwała nr 33 Komitetu ds. Światowego Dziedzictwa Kulturowego w Polsce z 30.11.2016 r. w sprawie propozycji umieszczenia na polskiej Liście informacyjnej młyna papierniczego w Dusznikach-Zdroju, teka DN.062.16.2017. 
